\title{
Non-acute coronary syndrome elevations of high-sensitivity troponin - a challenge for the emergency physician
}

\author{
Romanko I. ${ }^{\text {, }}$ Matias M. ${ }^{1}$, Romanko Ingrischová M. ${ }^{1,2}$ \\ 'Department of Anesthesiology and Intensive Care First Faculty of Medicine Charles University in Prague and General \\ University Hospital in Prague \\ ${ }^{2}$ Cardiology clinic, Medacor s.r.o.
}

High-sensitivity troponin (troponin I and troponin T) is serum marker specific for myocardial injury. Raised high-sensitivity troponin levels can be found in acute coronary syndrome, but also in a variety of other conditions as well. Differential diagnosis of high-sensitivity troponin elevations are a great challenge for emergency physicians. Apart from ruling-out acute coronary syndrome, other potential causes such as cardiovascular disease, infections, renal disease and age have to be considered. This narrative review discusses the possible insight of an emergency physician on non-ischaemic elevations of high-sensitivity troponin with a focus on prognostic value of high-sensitivity troponin.

Key words: troponin I, prognosis, infection, aging, myocardium, injury.

\section{Elevace vysoce senzitivního troponinu u stavů mimo akutní koronární syndrom - výzva pro lékaře urgentního př́ijmu}

Vysoce senzitivní troponin (troponin I a troponin T) je sérový marker specifický pro myokardiální lézi. Zvýšenou hladinu vysoce senzitivního troponinu Ize nalézt u akutního koronárního syndromu, ale také u řady jiných onemocnění. Diferenciální diagnostika zvýšených hodnot vysoce senzitivního troponinu představuje velkou výzvu pro lékaře urgentního př́ijmu. Kromě akutního koronárního syndromu se musí myslet i na další možné prííiny, naprííklad jiná kardiovaskulární onemocnění, infekce, onemocnění ledvin a také věk pacienta. Tento přehledový článek přináší náhled na zvýšení vysoce senzitivního troponinu z jiných než ischemických příčin a soustředí se na prognostický význam tohoto markeru.

Klíčová slova: troponin I, prognóza, infekce, stárnutí, myokard, poranění.

\section{Introduction}

Measuring troponin I (cTnl) and troponin T (cTnT) in serum, by high-sensitive assays (hs-cTn) enables the detection of this myocardium-specific marker at low concentrations. It is widely used for the diagnosis of acute coronary syndrome. Hs-cTnl makes the diagnosis quicker compared to conventional troponin assays. This has contributed to an increase in detection of non-ST-elevation myocardial infarction (NSTEMI), especially in it's early form [1].

A rise of circulating cTnl, although a hallmark of myocardial lesion, is not only specific for myocardial ischaemia. It is detectable in a variety of other disorders, usually connected with alterations of general well-being [2, 3].

Use of hs-cTnl in ruling-in or ruling-out the acute coronary syndrome has been discussed in many studies and guidelines [1, 2, 4-13]. Dynamic changes in serum hsTnl concentration over time are used to identify ongoing myocardial ischemia $[3,14,15]$. This is beyond the aim of this article, where we would like to focus on non-ischaemic elevations of hsTnl in the acute setting.

We intend not to comment all the potential diagnoses associated with hs-cTnl increase, but rather to show that increased biochemical markers of myocardial injury could be, apart from acute coronary syndrome (ACS), interpreted in context of mortality and/or adverse prognosis, aging and acute illness.

Physicians in emergency departments deal with differential diagnosis of chest pain, using biochemical markers of myocardial injury to rule-out acute coronary syndrome. With use of hs-cTnl, there are positive results in many cases, but the positivity itself does not rule-in 
acute coronary syndrome. Differentiation of acute coronary syndrome from non-ischaemic elevations of hs-cTnl can be challenging even for the experienced physician [16, 17]. One must carefully consider clinical signs and symptoms, ECG findings along with hs-cTnl dynamics, where appropriate [18]. Non-ischaemic etiologies should be considered. It is vital to know, what levels of hs-cTnl could be expected in chronic cardiovascular diseases, or various non-cardiac disorders. This is a quite complicated goal, as interindividual variability of hsTnl have been reported $[18,19]$. Therefore, hs-cTnl cannot be evaluated exquisitely, without context of other findings mentioned above.

\section{hsTnI as a prognostic marker}

Raised serum levels of hs-cTnl could predict cardiovascular complications, irrespective of primary condition. Surgical patients undergoing hip surgery, preoperatively diagnosed with increased hs-cTnl levels (median $99 \mathrm{ng} / \mathrm{l}$ ) on admission were found to have increased cardiac complications during hospitalization [20]. This study had a very small patient sample $(n=20)$ and 6 patients ended up with perioperative cardiac injury (congestive heart failure, arrhythmia, unstable angina). Out of these, 4 patients were known to have ischaemic heart disease prior to surgery and have hs-cTnl positive on admission. However, their primary diagnosis was not acute coronary syndrome despite of raised hs-cTnl on admission.

It has been reported by Metkus [21] that an increase in hs-cTnl during hospitalization worsens outcome of acute respiratory distress (ARDS) patients due to progressive myocardial injury.

They reported 2.27 fold increase risk of mortality $(p=0.002)$ in patients with an increase in hs- cTnl of more than $32.1 \%$ from baseline (between days 0 and 3). A rise in hs-cTnl levels prolonged the stay at intensive care unit (ICU) as well.

Heart failure is one of the conditions known to cause increase in hs-cTnl level. A study on 1096 patients showed that hs-cTnl has prognostic value in predicting adverse events in patients with heart failure [22]. The mean hs-cTnl levels in patients with heart failure with reduced ejection fraction (HFrEF) was $27.2 \mathrm{ng} / \mathrm{l}$ (13.5-65.5), while in patients with heart failure with preserved ejection fraction (HFpEF) it was $13.5 \mathrm{ng} / \mathrm{l}$ (5.8-23.3), p value less than 0.001. Coronary artery disease was more common in HFrEF group than in HFpEF group. There was no difference in diabetes occurrence in both groups. Hypertension and atrial fibrillation were more common in HFpEF group. The authors found that patients with hs-cTnl above the median had more coronary artery disease, renal dysfunction, higher BMI and tended to be men. All these factors along with biochemical markers of myocardial injury contribute to increased cardiovascular risk for these individuals. It also showed that systolic dysfunction is associated with higher levels of circulating hs-cTnl. However, hs-cTnl has been reported to be a better predictor of adverse events in HFpEF. Similar results regarding increased mortality in patients with HF, who had elevated hs-cTnl levels during follow up have been reported in study by Wallenbron [23]. Evidence supports the statement that increased hs-cTnl does not automatically point to acute coronary syndrome, but increases the risk of mortality and further hospitalizations from cardiac conditions on a long term basis [22-28].
Patients with higher hs-cTnl levels tend to be of older age and have a history of peripheral artery disease, heart failure, hypertension, coronary intervention, coronary artery disease and decrease in glomerular filtration rate [26]. Risk increases with the level of hs-cTnl [29], as well as severity of coronary artery disease [30]. Another cardiac condition, where hs-cTn plays a role as a prognostic marker is pulmonary embolism. It has been recently shown by a meta-analysis that patients with pulmonary embolism and increased cTn levels have increased mortality (irrespective of conventional or hs-cTn assay) [31]. cTn is also used for risk stratification of patients with pulmonary embolism, according to guidelines [32].

Ischaemic or non-ischaemic cardiac arrest could be associated with increased levels of hs-cTn. Raised hs-cTn in patients with non-ischaemic cardiac arrest corresponds with an increase in mortality following return of spontaneous circulation [33]. Although this study worked with hs-cTnT, we believe that the prognostic value of hs-cTnT is similar to that of hs-cTnl in conditions such as heart failure, respiratory distress or pulmonary embolism.

The question is how to transform this information into emergency decision making. Raised hs-cTnl without additional clinical suspicion of ACS means that the patient should be evaluated cautiously and a follow-up should be arranged to monitor cardiovascular outcome (myocardial infarction, stroke, cardiovascular death). Most of the studies use hs-cTnl to stratify patients into high or low-risk group according to hs-cTnl levels above, or under $99^{\text {th }}$ percentile. Absolute values of hs-cTnl are usually not mentioned. Therefore, it is complicated to get an insight of possible levels of hs-cTnl in cases where acute coronary syndrome is not suspected at the time of measurement. Moreover, upper reference limits for hs-cTnl vary significantly between assays. For example hs-cTnl assay from Abbott Laboratories used in study of Cavender [26] uses an upper reference limit (URL) of $26 \mathrm{ng} / \mathrm{l}$ (34.2 ng/I for males and $15.6 \mathrm{ng} / \mathrm{l}$ for females), while assay from Beckman Coulter uses $18.6 \mathrm{ng} / \mathrm{l}$ [34]. Assay from Siemens uses URL of $27 \mathrm{ng} / \mathrm{I}$ [29]. Another assays by Singulex has URL $10.2 \mathrm{ng} / \mathrm{l}$ for normal population [27], although in a work of Bonaca a cut off $9 \mathrm{ng} / \mathrm{I}$ was used [28]. These differences by manufacturer may be due to variable determination of healthy population in validation studies for each assay [35].

\section{Age related hsTn levels}

Increasing age is associated with progressive tissue vulnerability and damage [36]. This process has a molecular background (exposure of cells and organelles to oxidative stress) [37-39]. Various cardiac and non-cardiac conditions could cause a stress to myocardial muscle, causing a release of troponin (structural disease, valvulopathies, progressive atherosclerotic damage, acute illness, hypertension, tachyarrhythmia). This effect could be augmented by older age of myocardial muscle, making it more frail and susceptible to damage and dysfunction [38-41]. One can assume to detect increased hsTnl levels related to age group and pre-existing cardiovascular pathology. Along with aging, obesity and presence of diabetes are risk factors that increase a vessels vulnerability [42]. Similar effects on coronary vessels could be therefore presumed. Age is one of the factors associated with increased hsTnl 
levels in several studies. Motiwalla [27] reported a significant difference in age between patients with HF and hs-cTnl above URL (68 years) compared to patients with hs-cTnl below URL (60 years), p value 0.003 . Samman [30] reported that patients with higher baseline hs-cTnl tend to be older, but also have more severe coronary artery disease. Mean age and hs-cTnl for non-obstructive CAD were 61.1 years and $3.6 \mathrm{ng} / \mathrm{l}$ respectively, and for triple vessel disease 66.4 years and $5.7 \mathrm{ng} / \mathrm{l}$ and, respectively. Similar results concerning relation of hs-cTnl to age have been reported in other studies [24-27].

Reiter focused on 406 elderly (age 70 years or more) patients treated at emergency departments with ACS suspicion [14]. 308 were diagnosed with non-acute myocardial infarction (non-AMI), including 140 diagnosed with non-cardiac cause. hs-cTnT assay was used (Roche) Among elderly patients, higher prevalence of coronary artery disease, diabetes, hypertension and history of coronary intervention were reported compared to the younger group. Non-cardiac causes were not specified. The authors stated that elderly patients with non-AMI diagnosis had a significantly higher baseline hs-cTnT compared to younger patients (age below 70 years). Mean values for elderly and younger group were $14 \mathrm{ng} / \mathrm{l}$ and $4 \mathrm{ng} / \mathrm{l}$, respectively. However, the non-AMl group included unstable angina pectoris and other cardiac conditions (except coronary artery disease), which can both cause raise in hs-cTn. Thus, the reported results have to be taken cautiously. Raised hs-cTnl levels cannot be addressed to age only, although they can be expected to be found in the elderly population. This is probably a combination of progressive aging and increased severity of chronic conditions (cardiovascular or non-cardiovascular) associated with increasing age. Elevated hs-cTnl could point out to hitherto unrecognized cardiovascular disease.

\section{hsTn in acute non-cardiac illness}

As mentioned above, various non-cardiac conditions can cause an increase in hs-cTnl levels (summarized in Table 1). hs-cTnl assays have decreased specificity due to frequent occurrence of elevations above URL [17]. It is complicated to establish a mean values of hs-cTnl for noncardiac diagnoses, as there exists inter-individual variability. Moreover, various stages of pre- existing comorbidities could have an unpredictable additional impact on circulating hs-cTnl levels [14, 15]. Most studies do not focus on mean hs-cTnl levels in various non-cardiac conditions.

A Study by Korley reported an elevated hs-cTnl levels in 6.9\% of patients examined at emergency departments, in whom a non-cardiac diagnosis was concluded [24]. However, these other diagnoses were not specified.

Dhesi focused on a follow-up of patients presenting with non-cardiac primary diagnosis with an elevation of cTnl [43]. Study included 245 patients. Cardiovascular and non-cardiovascular mortality was a primary outcome. In accordance with literature findings, initially raised levels of cTnl were associated with increased mortality. Raised hs-cTnl did not alter primary management in these patients.

Mueller compared dynamic changes in hs-cTn kinetics in cohort of 165 ACS patients, 177 patients with unstable angina pectoris (UAP) and 442 non-ACS patients [44]. This study worked with hs-cTnT with URL 14 ng/l. Reported mean baseline values were 92.0 ng/l (27.3-312.3),
14.0 ng/l (5.1-26.8), 31.5 ng/l (19.5-60.4) for ACS, UAP and non-ACS patients, respectively. Mean values measured after 3 hours were $130.3 \mathrm{ng} / \mathrm{l}$ (46.4-378.5), $11.6 \mathrm{ng} / \mathrm{I}(5.0-25.5)$ and $31.3 \mathrm{ng} / \mathrm{I}(19.4-62.1)$ respectively. This showed that raised hs-cTn levels could be seen in non-ACS conditions, but without significant dynamic changes over time. Diagnoses included in non-ACS category were not specified.

Certain cardiac, non-ACS conditions, such as arrhythmias, tako-tsubo cardiomyopathy, hypertensive crisis or myocarditis could present with elevated levels of cTn. In addition, these conditions, could even present with dynamic changes in hs-cTnl [3]. This can complicate the rule-out of ACS, therefore other clinical features have to be considered cautiously.

hs-cTnl correlates with a decrease in glomerular filtration rate [45]. Patients with advanced kidney disease tend to have higher levels of circulating hs-cTnl, even if presenting with non- cardiac symptoms and signs in an acute setting. However, increased hs-cTnl points to a higher total cardiovascular risk in these patients, which is consistent with guidelines [46] and prognostic significance of hs-cTnl. There is a higher incidence of cardiovascular disease among patients with chronic kidney conditions [47].

In respiratory infections, such as pneumonia, raised levels of circulating cTn could be detected. Certain pathogens, for example streptococcus pneumoniae, cause direct damage to myocardium in animal

Tab. 1. Summary of possible etiology of raised hsTnl in serum [according to $2,3,40]$

\begin{tabular}{|l|}
\hline Coronary artery plaque rupture \\
\hline Intraluminal coronary artery thrombus formation \\
\hline Coronary artery spasm \\
\hline Coronary artery vasculitis or embolism \\
\hline Coronary artery endothelial dysfunction \\
\hline Coronary artery dissection \\
\hline Hypertension \\
\hline Left ventricle hypertrophy \\
\hline Hypertrophic obstructive cardiomyopathy \\
\hline Aortic dissection \\
\hline Aortic valve diseases \\
\hline Tachy/bradyarrhythmias \\
\hline Stress cardiomyopathy (tako-tsubo) \\
\hline Heart failure \\
\hline Severe anaemia \\
\hline Respiratory failure \\
\hline Myocarditis \\
\hline Cardiac contusion \\
\hline Rhabdomyolysis with cardiac muscle involvement \\
\hline $\begin{array}{l}\text { Cardiac surgery, defibrillation, catheter ablation, coronary revascularization } \\
\text { procedure }\end{array}$ \\
\hline Shock, hypotension \\
\hline Cardiotoxic drugs (anthracyclines, herceptin etc.) \\
\hline Infiltrative diseases - sarcoidosis, amyloidosis \\
\hline Strenuous exercise \\
\hline Sepsis and critically ill patient \\
\hline Pulmonary embolisms or severe pulmonary hypertension \\
\hline Renal failure, chronic kidney disease \\
\hline Acute neurological disease - stroke, subarachnoid haemorrhage \\
\hline Elder age \\
\hline
\end{tabular}


models [48]. In some patients this could be a sign of possible adverse cardiovascular outcome during disease course (e.g. myocardial infarction) [49]. Similar changes have been reported in influenza infections [50]. Severe infections can lead to sepsis, which can deteriorate into septic shock. Both sepsis and septic shock are associated with raised levels of c-Tnl and hs-cTnl [51, 52]. Elevated hs-TnT and its dynamic changes plays a role of prognostic marker in this condition and is associated with increased mortality of patients with shock [51].

Strenuous exercise is another condition which can cause myocardial injury. According to meta-analysis by Sedaghat [53] increase in cTn could be dominantly seen in endurance activities, such as marathon, running, triathlon, cycling, rugby. Studies included in this meta-analysis worked with cTnT, cTnl and hs-cTnT. It could be expected that extension of myocardial injury would depend on level of activity and physical fitness.

Chronic pulmonary diseases (e.g. COPD) may cause pulmonary hypertension leading to right heart failure. Course of chronic obstructive pulmonary disease (COPD) is typical for its acute exacerbations. This acute condition can lead to myocardial dysfunction with increase in cTn.

Apart from that, chronic heart failure itself is associated with increase of cTn. In a recent study, dynamic change of cTn (study used conventional CTnT) levels in patients with exacerbation of COPD was attributed to the use of beta2-agonist as therapeutic agents [54].

\section{Summary}

Cardiac and non-cardiac conditions associated with raised hs-cTnl levels have been described in several reviews, guidelines and certain studies. We have discussed the role of hs-cTnl as prognostic marker of adverse cardiovascular outcome and/or mortality. Patients with various other comorbidities apart from CAD and heart failure (e.g. COPD) could have increased risk of cardiovascular events due to increased levels of hsTnl [55]. This might point out to possibly unrecognized coronary artery disease.

Age is one of the factors contributing to increased mortality in many diseases. Regarding hs-cTnl, we assume that elder age could lead to elevated levels of hs-cTn, due to increased tissue fragility. On the other hand, one cannot exclude presence of unrecognized cardiovascular diseases (e.g. CAD) in elderly patients. Age is one of independent risk factors for cardiovascular diseases. However, an elderly patient, with severe acute illness, is likely to have an increased level of biochemical markers of myocardial injury.

There are several non-cardiac conditions that could directly affect myocardial muscle, without causing ischemia. These conditions could mimic ACS in acute setting. It is not specified in literature, what levels of hs-cTn are typical for ACS and what for non-ACS conditions.

Differentiation is usually made by serial measurements of hs-cTn in time with regard to other clinical features (as mentioned above, several non-ACS conditions could present with dynamic changes in hs-cTn). In addition, various hs-cTn biochemical assays have different cut-off values. We think it is vital for physicians to know, that such conditions exist and are associated with elevated levels of hs-cTn. In case of clinical suspicion or uncertainty, ACS should be excluded according to proper guidelines.

\section{Conclusions}

HsTnl is a sensitive marker for detection of myocardial injury. It is an important diagnostic tool in emergency departments for suspected acute coronary syndrome. Precise guidelines have been developed to rule-in or rule-out ACS in emergency settings.

Its use for differentiation of cardiac and non-cardiac diagnosis is limited due to decrease in specificity. Structural heart diseases, arrhythmias, severe infections, stroke, renal insufficiency, strenuous exercise and many other conditions could cause non-ischaemic myocardial injury.

Physicians have to carefully analyse signs, symptoms and consider additional conditions such as age, coronary artery disease, chronic heart failure, hypertension. HsTnl is a prognostic marker and raised levels could point to increased cardiovascular mortality, or to yet undiagnosed coronary disease, which becomes apparent in context of ongoing acute disease. In such cases, patients should be discharged carefully, with a specialist follow-up arranged, if necessary.

PROHLÁŠENÍ AUTORŮ: Prohlášení o původnosti: Práce je původní a nebyla publikována ani není zaslána k recenznímu ř́zení do jiného média. Střet zájmů: Autoři prohlašují, že nemají stř̌et zájmů v souvislosti s tématem práce. Podíl autorů: Všichni autoři rukopis četli, souhlasí s jeho zněním a zasláním do redakce časopisu Anesteziologie a intenzivní medicína. RI se podílel sepsáním vlastního textu a vyhledáváním literatury, MM a MRI se na článku podíleli odbornou revizí textu a připomínkami k doplnění. Financování: Žádné.

\section{LITERATURE}

1. Roffi M, Patrono C, Collet JP, Mueller C, Valgimigli M, Andreotti F, et al. 2015 ESC Guidelines for the management of acute coronary syndromes in patients presenting without persistent ST-segment elevation: Task Force for the Management of Acute Coronary Syndromes in Patients Presenting without Persistent ST-Segment Elevation of the European Society of Cardiology (ESC). European Heart Journal 2016; 37(3): 267-315.

2. Thygesen K, Alpert JS, Jaffe AS, Chaitman BR, Bax JJ, Morrow DA, et al. Fourth universa definition of myocardial infarction. European Heart Journal 2019; 40(3): 237-269.

3. Wildi K, Twerenbold R, Mueller Ch. How acute changes in cardiac troponin concentrations help to handle the challenges posed by troponin elevations in non-ACS- patients. Clin Biochem 2015; 48(4-5): 218-222

4. Reichlin T, Hochholzer W, Bassetti S, Steuer S, Stelzig C, Hartwiger S, et al. Early diagnosis of myocardial infarction with sensitive cardiac troponin assays. N Engl J Med 2009; 361(9): 858-867.
5. Keller T, Zeller T, Peetz D, Tzikas S, Roth A, Czyz E, et al. Sensitive troponin I assay in early diagnosis of acute myocardial infarction. N Engl J Med 2009; 361(9): 868-877.

6. Weber M, Bazzino O, Navarro Estrada JL, de Miguel R, Salzberg S, Fuselli JJ, et al. Improved diagnostic and prognostic performance of a new high-sensitive troponin T assay in patients with acute coronary syndrome. Am Heart J 2011; 162(1): 81-88.

7. Agewall S, Giannitsis E, Jernberg T, Katus H. Troponin elevation in coronary vs. noncoronary disease. Eur Heart J 2011; 32(4): 404-411.

8. Wu AH, Jaffe AS. The clinical need for high-sensitivity cardiac troponin assays for acute coronary syndromes and the role for serial testing. Am Heart J 2008; 155(2): 208-214.

9. Wu A, Lu QA, Todd J, Moecks J, Wians F. Short- and long-term biological variation in cardiac troponin I measured with a high-sensitivity assay: implications for clinical practice. Clin Chem 2009; 55(1): 52-58. 
10. Saunders JT, Nambi V, de Lemos JA, Chambless LE, Virani SS, Boerwinkle E, et al. Cardiac troponin T measured by a highly sensitive assay predicts coronary heart disease, heart failure, and mortality in the Atherosclerosis Risk in Communities Study. Circulation 2011; 123(13): 1367-1376.

11. De Lemos J, Drazner MH, Omland T, Ayers CR, Khera A, Rohatgi A, et al. Association of troponin $T$ detected with a highly sensitive assay and cardiac structure and mortality risk in the general population. JAMA 2010; 304(22): 2503-2512.

12. Kawahara C, Tsutamoto T, Nishiyama K, Yamaji M, Sakai H, Fujii M, et al. Prognostic role of high-sensitivity cardiac troponin $\mathrm{T}$ in patients with nonischemic dilated cardiomyopathy. Circ J 2011; 75(3): 656-661.

13. Brichko L, Schneider HG, Chan W, Seah J, Smit V, Dart A, et al. Rapid and safe discharge from the emergency department: A single troponin to exclude acute myocardial infarction. Emerg Med Australas 2018; 30(4): 486-493.

14. Reiter M, Twerenbold R, Reichlin T, Haaf P, Peter F, Meissner J, et al. Early diagnosis of acute myocardial infarction in the elderly using more sensitive cardiac troponin assays. Eur Heart J 2011; 32(11): 1379-1389.

15. Reiter M, Twerenbold R, Reichlin T, Benz B, Haaf P, Meissner J, et al. Early diagnosis of acute myocardial infarction in patients with pre-existing coronary artery disease using more sensitive cardiac troponin assays. Eur Heart J 2011; 33(8): 988-997.

16. Hickman PE, Lindahl B, Cullen L, Koerbin G, Tate J, Potter JM. Decision limits and the reporting of cardiac troponin: Meeting the needs of both the cardiologist and the ED physician. Crit Rev Clin Lab Sci 2015; 52(1): 28-44.

17. Kozinski M, Krintus M, Kubica J, Sypniewska G. High-sensitivity cardiac troponin assays: From improved analytical performance to enhanced risk stratification. Crit Rev Clin Lab Sci 2017; 54(3): 143-172.

18. Bhoi S, Verma P, Vankar S, Galwankar S. High sensitivity troponins and conventional troponins at the bedside. Int J Crit IIIn Inj Sci 2014; 4(3): 253-256.

19. Wu AH, Agee SJ, Lu QA, Todd J, Jaffe AS. Specificity of a high-sensitivity cardiac troponin I assay using single-molecule-counting technology. Clin Chem 2009; 55(1): 196-198

20. Sa-Ngasoongsong P, Thamyongkit S, Kulachote N, Luksameearunothai K, Ngamukos T, Suphachatwong C. Usefulness of Serum Cardiac Biomarkers for Predicting In-Hospita Cardiac Complications in Acute Hip Fracture: A Prospective Cohort in 20 High Surgical Risk patients with Age over 55 Years. Biomed Res Int 2018; 5: 3453652

21. Metkus TS, Guallar E, Sokoll L, Morrow DA, Tomaselli G, Brower R, et al. Progressive myocardial injury is associated with mortality in the acute respiratory distress syndrome. J Crit Care 2018; 48: 26-31.

22. Gohar A, Chong JPC, Liew OW, den Ruijter H, de Kleijn DPV, Sim D, et al. The prognostic value of highly sensitive cardiac troponin assays for adverse events in men and women with stable heart failure and a preserved vs. reduced ejection fraction. Eur J Heart Fail 2017; 19(12): 1638-1647.

23. Wallenborn J, Marx A, Störk S, Güder G, Brenner S, Ertl G, et al. Prognostic significance of serial high-sensitivity troponin I measurements following acute cardiac decompensation-correlation with longer-term clinical outcomes and reverse remodelling. Int J Cardiol 2017; 232: 199-207.

24. Korley FK, Schulman SP, Sokoll LJ, DeFilippis AP, Stolbach Al, Bayram JD, et al. Troponin Elevations Only Detected With a High sensitivity Assay: Clinical Correlations and Prognostic Significance. Acad Emerg Med 2014; 21(7): 727-735.

25. Lewis JR, Lim WH, Wong G, Abbs S, Zhu K, Lim EM, et al. Association Between High-Sensitivity Cardiac Troponin I and Cardiac Events in Elderly Women. J Am Heart Assoc 2017; 6(8).

26. Cavender MA, White WB, Jarolim P, Bakris GL, Cushman WC, Kupfer S, et al. Serial Measurement of High-Sensitivity Troponin I and Cardiovascular Outcomes in Patients With Type 2 Diabetes Mellitus in the EXAMINE Trial (Examination of Cardiovascular Outcomes With Alogliptin Versus Standard of Care). Circulation 2017; 135(20): 1911-1921.

27. Motiwala SR, Gaggin HK, Gandhi PU, Belcher A, Weiner RB, Baggish AL, et al. Concentrations of highly sensitive cardiac troponin-l predict poor cardiovascular out comes and adverse remodeling in chronic heart failure. J Cardiovasc Transl Res 2015; 8(3): 164-172.

28. Bonaca MP, O'Malley RG, Murphy SA, Jarolim P, Conrad MJ, Braunwald E, et al. Prognostic performance of a high-sensitivity assay for cardiac troponin I after non-ST elevation acute coronary syndrome: Analysis from MERLIN-TIMI 36. Eur Heart J Acute Cardiovasc Care $2015 ; 4(5): 431-440$

29. Liu T, Wang G, Li P, Dai X. Risk classification of highly sensitive troponin I predict presence of vulnerable plaque assessed by dual source coronary computed tomography angiography. Int J Cardiovasc Imaging 2017; 33(11): 1831-1839.

30. Samman Tahhan A, Sandesara P, Hayek SS, Hammadah M, Alkhoder A, Kelli HM, et al High-Sensitivity Troponin I Levels and Coronary Artery Disease Severity, Progression, and Long-Term Outcomes. J Am Heart Assoc 2018; 7(5).

31. El-Menyar A, Sathian B, Al-Thani H.Elevated serum cardiac troponin and mortality in acute pulmonary embolism: Systematic review and meta-analysis. Respir Med. 2019 Aug 23; $157: 26-35$.
32. Konstantinides SV, Torbicki A, Agnelli G, Danchin N, Fitzmaurice D, Galiè N, et al. 2014 ESC guidelines on the diagnosis and management of acute pulmonary embolism. Eur Heart J. 2014 Nov 14; 35(43): 3033-3069, 3069a-3069k.

33. Gilje P, Koul S, Thomsen JH, Devaux Y, Friberg H, Kuiper M, et al. High-sensitivity troponin-T as a prognostic marker after out-of-hospital cardiac arrest - A targeted temperature management (TTM) trial substudy. Resuscitation. 2016 Oct; 107: 156-161.

34. Pretorius CJ, Tate JR, Wilgen U, Cullen L, Ungerer JPJ. A critical evaluation of the Beckman Coulter Access hsTnl: Analytical performance, reference interval and concordance. Clin Biochem 2018; 55: 49-55.

35. Collinson PO, Heung YM, Gaze D, Boa F, Senior R, Christenson R, et al. Influence of population selection on the 99 th percentile reference value for cardiac troponin assays. Clin Chem 2012; 58: 219-225.

36. Niccoli T, Partridge L. Ageing as a risk factor for disease. Current Biology 2012; 22(17): $741-752$.

37. Oliver DMA, Reddy PH. Molecular Basis of Alzheimer's Disease: Focus on Mitochondria. J Alzheimers Dis. 2019; 22.

38. Cianflone E, Torella M, Chimenti C, De Angelis A, Beltrami AP, Urbanek K, et al. Adult Cardiac Stem Cell Aging: A Reversible Stochastic Phenomenon? Oxid Med Cell Longev 2019; 7: 5813147

39. Nagel F, Santer D, Stojkovic S, Kaun C, Schaefer AK, Kršák M, et al. The impact of age on cardiac function and extracellular matrix component expression in adverse post-infarction remodeling in mice. Exp Gerontol 2019; 119: 193-202.

40. Boyle AJ, Shih H, Hwang J, Ye J, Lee B, Zhang Y, et al. Cardiomyopathy of aging in the mammalian heart is characterized by myocardial hypertrophy, fibrosis and a predisposition towards cardiomyocyte apoptosis and autophagy. Experimental Gerontology. 2011; 46(7): 549-559.

41. Dai D-F, Chen T, Johnson SC, Szeto H, Rabinovitch PS. Cardiac aging: from molecular mechanisms to significance in human health and disease. Antioxidants \& Redox Signaling 2012; 16(12): 1492-1526.

42. Anttila E, Balzani D, Desyatova A, Deegan P, MacTaggart J, Kamenskiy A. Mechanical damage characterization in human femoropopliteal arteries of different ages. Acta Biomater 2019; 90: 225-240.

43. Dhesi S, Shanks M, Tymchak WJ. Troponin rise in hospitalized patients with nonacute coronary syndrome: retrospective assessment of outcomes and predictors. Can J Cardiol 2015; 31(3): 296-301.

44. Mueller M, Biener M, Vafaie M, Doerr S, Keller T, Blankenberg S. Absolute and relative kinetic changes of high-sensitivity cardiac troponin $\mathrm{T}$ in acute coronary syndrome and in patients with increased troponin in the absence of acute coronary syndrome. Clin Chem 2012; 58(1): 209-218.

45. Bjurman Ch, Petzold M, Venge P, Farbemo J, Fu M, Hammarsten O. High-sensitive cardiac troponin, NT-proBNP, hFABP and copeptin levels in relation to glomerular filtration rates and a medical record of cardiovascular disease. Clin Biochem 2015; 48(4-5): 302-307. 46. Piepoli MF, Hoes AW, Agewall S, Albus Ch, Brotons C, Catapano AL, et al. 2016 European Guidelines on cardiovascular disease prevention in clinical practice: The Sixth Joint Task Force of the European Society of Cardiology and Other Societies on Cardiovascular Disease Prevention in Clinical Practice (constituted by representatives of 10 societies and by invited experts). European Heart Journal 2016; 37(29): 2315-2381.

47. Members KB. Chapter 4: other complications of CKD: CVD, medication dosage, patient safety, infections, hospitalizations, and caveats for investigating complications of CKD. Kidney Inter 2013; Suppl. 3.

48. Brack MC, Lienau J, Kuebler WM, Witzenrath M. Cardiovascular sequelae of pneumonia. Curr Opin Pulm Med 2019; 25(3): 257-262.

49. Musher DM, Abers MS, Corrales-Medina VF. Acute Infection and Myocardial Infarction. N Engl J Med 2019; 380(2): 171-176.

50. Harris JE, Shah PJ, Korimilli V, Win H. Frequency of troponin elevations in patients with influenza infection during the 2017-2018 influenza season. Int J Cardiol Heart Vasc 2019; 22: $145-147$.

51. Jendoubi A, Jerbi S, Maamar E, Abbess A, Samoud Z, Kanzari L, et al. Prognostic Value of High-sensitivity Troponin I in Patients with Septic Shock: A Prospective Observational Study. Indian J Crit Care Med. 2019 Jul; 23(7): 320-325.

52. Su WL, Shui HA, Lan CC, Yang MC, Hsieh CA, Jang SJ, et al. Cardiovascular Parameters Associated With Troponin I as Indicators for 14-Day Mortality in Patients With Septic Shock. Am J Med Sci. 2018 Sep; 356(3): 244-253.

53. Sedaghat-Hamedani F, Kayvanpour E, Frankenstein L, Mereles D, Amr A, Buss S, et al. Biomarker changes after strenuous exercise can mimic pulmonary embolism and cardiac injury--a metaanalysis of 45 studies. Clin Chem. 2015 Oct; 61(10): 1246-1255.

54. Shafuddin E, Chang CL, Cooray M, Tuffery CM, Hopping SJ, et al. Changes in biomarkers of cardiac dysfunction during exacerbations of chronic obstructive pulmonary disease. Respir Med. 2018 Dec; 145: 192-199.

55. Adamson PD, Anderson JA, Brook PR, Calverley PMA, Celli BR, Cowans NJ, et al. Cardiac Troponin I and Cardiovascular Risk in Patients With Chronic Obstructive Pulmonary Disease. J Am Coll Cardiol. 2018 Sep 4; 72(10): 1126-1137. 